\title{
Occupational Health in Japan
}

\author{
-The Future Role of UOEH*-
}

J. Corbett McDonald

Professor of Epidemiology and Occupational Medicine, School of Occupational Health, McGill University. Montreal, Canada

\section{Introduction}

The striking feature of UOEH is its name. So far as I am aware, there is no other university dedicated solely to occupational and environmental health. In choosing the name, the founders acquired not just an eye-catching title but made clear their intention to create something quite new. There have been departments, institutes and even schools of occupational health: what more is implied by the word university and can it be achieved? The term has such a variety of meanings and usages that it could cover almost any establishment concerned with higher education and quite a few others beside. However, I am sure the founders of UOEH were less ambiguous; like me they knew that universities operate only at the highest level of learning, are comprehensive in covering all related disciplines, and are centres capable of intellectual leadership, at least nationally. The departments, institutes and schools in which I have worked would claim some of the same attributes but as part of the university to which they belonged. UOEH must accomplish the task on its own.

Universities, whether publicly or privately funded, have three main functions of potentially equal importance. First is the advancement and consolidation of knowledge by study and research, second is its dissemination by true education (as opposed to vocational training), and third, its application to the needs of the community. To some extent all institutions concerned with education or research have similar functions but usually their terms of reference and objectives are more precisely defined than for universities. Universities have traditionally enjoyed very great freedom, but this does not imply licence. Society has the right, which it has sometimes exercised, to expect that those who enjoy special privileges consider carefully how best to use them. The staff of this university is well aware of all this and are already thinking hard and responsibly about it. This paper will not aim to provide them with answers, rather with further food for thought.

\footnotetext{
* Based on a lecture given while a Visiting Professor at UOEH, November 21, 1983.
} 
Table 1. Establishments and employees by size of establishment

\begin{tabular}{|c|c|c|c|c|}
\hline \multirow[b]{2}{*}{ Size } & \multicolumn{2}{|c|}{ Establishments } & \multicolumn{2}{|c|}{ Employees } \\
\hline & All & Manufacturing & All & Manufacturing \\
\hline$<100$ & $6,250,304(99 \%)$ & $856,254 \quad(98 \%)$ & $35,472,036 \quad(77 \%)$ & $7,610,268 \quad(59 \%)$ \\
\hline $100-299$ & 32,900 & 12,080 & $5,165,875(11 \%)$ & $1,941,646(15 \%)$ \\
\hline $300-499$ & 4,148 & 1,991 & $1,567,128(3 \%)$ & $757.987(6 \%)$ \\
\hline $500-999$ & 2,268 & 1,324 & $1,532,827(3 \%)$ & $900,184 \quad(7 \%)$ \\
\hline $1000+$ & 1,083 & 749 & $2,223,400(5 \%)$ & $1,652,832(12 \%)$ \\
\hline Total & $6,290,703$ & 872,398 & $45,961,266$ & $12,862,917$ \\
\hline
\end{tabular}

Table 2. Frequency of industrial injuries by size of establishment

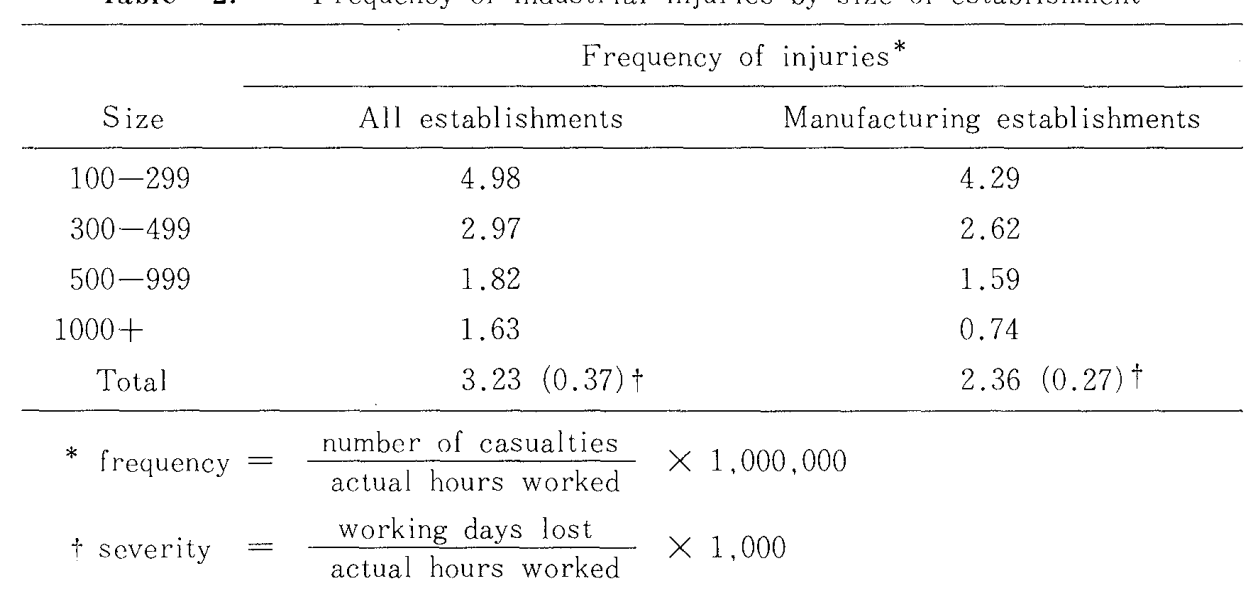

Table 3. Distribution of large and smaller establishments by main occupational groups

\begin{tabular}{|c|c|c|c|c|}
\hline & \multicolumn{2}{|c|}{ Large $(3.351)$} & \multicolumn{2}{|c|}{ Smaller $(6,290,352)$} \\
\hline Mining & 16 & \multirow{2}{*}{$5 \%$} & 6,953 & \multirow{2}{*}{$9 \%$} \\
\hline Construction & $152\}$ & & $550.317\}$ & \\
\hline Manufacture & 2.073 & \multirow[t]{2}{*}{$62 \%$} & 870.325 & \multirow[t]{2}{*}{$14 \%$} \\
\hline Wholesale/ retail & 320 & & $3,025,049$ & \\
\hline Finance/insurance & 157 & \multirow[t]{2}{*}{$15 \%$} & 83,481 & \multirow[t]{2}{*}{$53 \%$} \\
\hline Real cstate & 10 & & 237.530 & \\
\hline Transport/communication & 159 & \multirow{3}{*}{$18 \%$} & 133.250 & \multirow{3}{*}{$24 \%$} \\
\hline Electricity, gas, water, steam & 41 & & 4,680 & \\
\hline Services & 417 & & $1,354,141$ & \\
\hline
\end{tabular}


Table 4. Distribution of large and smaller establishments in manufacturing sector by type of product

\begin{tabular}{lrrrr}
\hline & Large & $(2,073)$ & Smaller & $(870,325)$ \\
\hline Electrical machinery and equipment & 454 & $27 \%$ & 40,528 & $6 \%$ \\
Precision equipment & 102 & & 15,737 & $6 \%$ \\
Transport equipment & 293 & & 25,502 & \\
Ordinary machinery & 215 & $32 \%$ & 70,826 & $25 \%$ \\
Metal products & 157 & & 117,477 & \\
Iron and Steel & 100 & $5 \%$ & 8,951 & $1 \%$ \\
Textiles & 114 & $5 \%$ & 181,432 & $20 \%$ \\
Petrochemicals & 233 & $11 \%$ & 9,752 & $1 \%$ \\
Other & 405 & $20 \%$ & 400,120 & $46 \%$ \\
\hline
\end{tabular}

Table 5. Proportion of employees in dangerous occupations by size of establishment

\begin{tabular}{cc}
\hline No. employees & With dangerous occupation $(\%)$ \\
\hline $30-99$ & $12.7 \%$ \\
$100-499$ & $16.6 \%$ \\
$500-999$ & $21.9 \%$ \\
$1000+$ & $25.2 \%$ \\
\hline
\end{tabular}

\section{Occupational Health in Japan}

In a recent address to the British Association (McDonald, 1981), I examined the evolution and future requirements of occupational health services in the United Kingdom. My ideas had been developed in Canada a year or two earlier and the conclusions required little modification for translation to Europe. Here in Japan, I find that the situation is again remarkably similar, despite rather obvious but superficial differences. In most industrialized countries, occupational health services are virtually confined to the large private industries with little or nothing in those with fewer than 500 employees. Yet it is in the smaller companies that most people work and where conditions are often least well regulated. The reasons for this state of affairs are partly ignorance as to the nature of the hazards and the methods of control and partly economic.

Japan is no exception, Table 1, derived from data published in the 1981 Year Book of Labour Statistics (Ministry of Labour, Japan, 1983), shows that of 6,290,703 industrial establishments, only $3,351(0.05 \%)$ had 500 or more employees. Eight percent of all Japanese employees work in such establishments whereas $77 \%$ are in workplaces with fewer than 100 employees. In the manufacturing sector, the pattern is similar. Industrial injury rates, on the other hand, are three times higher in the smaller establishments than the larger ones (Table 2), and over six times higher in 
manufacturing. With the exception of mining, upset by very high accident rates in the large coal mines, other industrial sectors show the same pattern. These gradients are the more remarkable in that there is little to suggest that the large companies are mainly in the safer industries. Table 3 shows that manufacturing plants predominate among the larger establishments, offices and shops among the smaller. Within the manufacturing sector, the distributions by types of product (Table 4) offer no obvious explanation; indeed, statistics from the Ministry of Labour (Table 5) strongly suggest that there is a direct relationship between size of establishment and the proportion of employees in dangerous jobs. It does not follow of course that the more favorable accident experience of large companies is necessarily attributable to their generally better health and safety services, but the high rates of injury in small plants clearly indicate where the problem now lies.

The Industrial Safety and Health Law of 1972 (Japan Industrial Safety and Health Association, 1983), requires that companies with 1,000 or more employees (500 or more in certain hazardous circumstances) should appoint an industrial physician for their exclusive service. In fact, there are only 900 or so full-time occupational physicians in Japan, few have had significant post-graduate training and most of them $(96 \%)$ are in clinical practice, working only part-time in industry. Occupational health nurses ase also scarce; there are said to be only about 1,000 nurses employed in Japanese industry, some trained in public health and very few specifically for work in industry. The most serious deficiency is the almost complete absence of occupational hygienists. No doubt, various engineers and other technical staff perform at least part of the task of environmental monitoring and control but, again, the lack of fully trained professionals in this country should be a matter of some concern.

Although medical science underlies most activities in occupational health, clinical skills have limited application. Diseases and accidents attributable to work do not differ from similar conditions caused by nonoccupational factors. Problems of diagnosis and management are within the competence of the community's general medical services so there is no sense in duplicating them. Certain activities at the workplace such as first aid and minor treatment, pre-employment and periodic health examinations, screening tests for presymptomatic detection of diseases (occupational and other) and advice on health matters have an important clinical content. Physicians trained in preventive medicine should design and supervise these activities. However, the work itself can be economically preformed by nurses or paramedical staff with appropriate training.

\section{The Need}

An adequate system of occupational health and safety for all workers entails much more than a. sufficient supply of occupational physicians, however well-trained. Most occupational diseases and injuries - especially the more serious - are not amenable to 
medical or surgical treatment except as a means of reducing complications and preserving residual function. For example, fatal and disabling accidents, occupational cancers, pneumoconioses, occupational asthmas, degeneration of bones and joints, hazards to the fetus, damage to the nervous system, can be controlled only by preventive measures. These measures require the closely coordinated knowledge and skills of many disciplines: epidemiology to identify and assess environmental risks, toxicology to explain and sometimes forecast them and hygiene and engineering to monitor and control. Furthermore, health and safety at work are not purely matters of science and technology; they cannot be achieved simply by laws, regulations, inspection and enforcement. Worker management participation in self-regulating processes is vitally necessary if optimal rather than minimal standards are the aim. These political and socio-economic considerations are so fundamental that physicians and other health professionals in industry who are not educated to appreciate and apply them may do more harm than good.

After review of analogous but less serious problems in both Canada and the UK, I concluded that an adequate system of occupational health had four essential elements:-

1. Basic occupational health services for all employed persons with access to laboratories and expert advice. These services should include systematic inspection of the workplace, initial and periodic health screening and efficient emergency facilities.

2. A comprehensive system of epidemiological and toxicological surveillance and research to ensure prevention and earliest possible detection of occupational hazards.

3. A formula to encourage collaboration and reduce conflict between employers, employees and government in matters of health and safety. This should clarify the responsibility of the general health services and of each main sector of industry.

4. A rational policy to ensure training of a sufficient number of health and safety personnel for these services.

I believe that Japan has equivalent needs. The first requirement listed above is clearly not met, despite enormous emphasis here on routine medical examinations by physicians-a practice often performed by nurses elsewhere. I wonder, too, whether Japan has an adequate framework for epidemiological and toxicological surveillance and research, sufficient for detection and control of new occupational hazards with minimum delay. So far as the third element is concerned, the situation may be better here than in the west but there remains the same need for active participation of each major industrial sector and of the general health services. Most pressing of all, having regard for the serious lack of trained professional manpower in occupational health, is the need to develop a strategy appropriate to Japan's needs for trained personnel in large and small industry.

In the United Kingdom, with only half the labour force of Japan, a full-time occupational physician for every 2,000-3,000 workers would require about 10,000 doctors 
(McDonald, 1981). This did not seem to me either possible or desirable; physicians are overtrained for most of the work and not well suited to much of the rest. I believe it more rational to regard occupational medicine as a field of specialization for a relatively small but highly trained group of physicians. Their expertise should be mainly in appropriate aspects of preventive medicine, especially epidemiology, toxicology, work physiology and health service management. They require to be complemented by a) other specialists - industrial hygienists, engineers, ergonomists, statisticians, etc. and b) less specialized 'primary' occupational services at the workplace, (not forgetting the many employees in small enterprises). Although well trained part-time occupational physicians can make an important contribution especially in middle-sized plants, nursing help is still needed whereas a qualified occupational health nurse alone would be sufficient. An alternative is the occupational health technician specifically trained for the task. Such 'technicians' constitute the general approach in Eastern Europe and a similar training is becoming available at a few universities and technical colleges in the USA and the UK. Ideally, such courses are at bachelor's degree level with emphasis on environmental measurement, basic epidemiological methods and primary (emergency) health care procedures.

The Japanese situation is different from that in the UK in several respects. The labour force is twice as big, so it is not surprising that some 25,000 'occupational physicians' (mostly part-time) are already employed in private manufacturing companies with 50 or more employees (Ministry of Labour, Japan, 1980). Despite their lack of formal training, the potential value of this large body of physicians, many undoubtedly interested in their job, should not be underestimated. A second important asset is the requirement on all manufacturing establishments with 50 or more employees to appoint 'health supervisors'. Almost $90 \%$ of the companies have fulfilled this requirement and also many smaller companies not legally obliged to do so. Altogether nearly 50,000 health supervisors are now in post in manufacturing alone (Ministry of Labour, Japan, 1980). Their level of knowledge and training may be quite limited but their potential is great. On the debit side, there is the dearth of occupational health nurses and hygienists, the latter to some degree offset by provisions of the Working Environment Measurement Law (1975). This law specifically requires that training courses be set up by Prefectural Labour Standards Offices for duly qualified persons who wish to be registered as 'working environment measurement experts'. Such experts are not occupational hygienists but a basis now exists from which a more comprehensive training program could develop.

\section{Objectives for UOEH}

\section{Education}

In 1981 Professor Tsuchiya (1982) outlined his plans for an Institute of Industrial 
Ecological Sciences which he hoped would become a national and international centre of occupational and environmental health education. In a recent re-statement of this plan (Tsuchiya, 1983) the President again emphasized the need for a graduate school of occupational health because medical sciences alone cannot cover all the natural and cultural sciences required. He proposed that the School of Nursing should expand to include a School of Industrial Nursing and the School of Medical Technology to become a School of Industrial Ecological Science. Implicitly, the graduate school would cover all relevant disciplines and could provide post-graduate training at various levels for students with a wide range of backgrounds. Because three ministries-education, labour and health and welfare-are involved, each with their separate views and priorities, future development may entail some compromises. Moreover, the occupational health problems of a nation with an economically active population of over 56 million (1981), including some 40 million who are salaried or wage earners, cannot possibly be met by the output of a single graduate school. Hence the need for UOEH to consider carefully its role within a realistic professional manpower strategy which it may itself have to initiate.

Despite the deficiencies of the present system, its considerable strengths call for development and improvement rather than radical change. To help in this process, I suggest that UOEH should channel its educational efforts along two main lines:-

(1) The training of a core of first class professionals in occupational medicine, nursing and hygiene to serve as a standard against which others in the field can be judged. Quality not quantity should be the aim.

(2) The development of courses of further education for the mainly part-time occupational physicians and for nurses and measurement experts already working in industry. Emphasis should be on accessibility with fullest use of video methods and equipment.

Success will depend on the quality of the courses offered and on whether incentives can be created to acquire more professional knowledge and competence. The incentive question is certainly difficult, but perhaps the most important aspect of the educational aims. Employers and labour leaders will have to learn the advantage of having the advice and services of doctors, nurses and hygienists who are fully informed and competent. Health and safety at work are not exceptions to what they would expect in most other aspects of life.

Experience of postgraduate training in occupational health at London University and at McGill leads me to recommend a 'progressive' pattern of education. During the elementary phase, lasting 3 or 4 months, a common set of courses, dealing with work, health and disease, epidemiology and statistics, and monitoring and control methods, is offered to all students, whatever their background or career objectives. During the intermediate phase, lasting 6 or 7 months, there is separation into environmental, health and other streams, each dealing in more detail with the measurement, monitoring and preven- 
tive methods to meet the special needs of various groups, e.g. physicians, toxicologists, nurses, hygienists, psychologists, statisticians, etc. Finally, at the advanced level, students with investigative interests and potential are given more individual training and practice in the design, conduct and analysis of research. The latter phase will occupy at least 2 years. This general pattern is intended to give all professionals in the field a common background, yet permit students to advance through the program so far as they are able. The diplomas, degrees and certificates awarded on completion of each phase are a matter of local custom.

The structure of the training program will largely determine the functional structure of the graduate school. Each major educational component will require a 'department' with academic responsibilities. Departmental divisions often lead to separatism, sometimes even uncooperative rivalry, but these problems can be overcome if research and service activities (see below) are organized on an interdepartmental basis. But for education, as such, and to ensure reasonable career prospects for staff, departments are necessary. In the future graduate school of UOEH, at least six will be needed to cover the main components:-

(1) Occupational medicine

- clinical and experimental toxicology

- physiology and psychology

(2) Occupational epidemiology and statistics

- social demography

- computing

(3) Industrial ecology

- technology and economics

(4) Hygiene and engineering

- physical, chemical and biological hazard control

- ergonomics and personal protection

(5) Health services administration

- planning, management, evaluation

- professional manpower development

(6) Information and library services

\section{Research}

The weakness of academic research everywhere is that it is subject to the pressures of 'publish or perish'. Concern tends to be for studies which can be quickly and economically completed and produce short papers for professional journals or presentation at the next conference. Relevance of the research to the real world of occupational health is seldom an important factor. The problem is made worse by heavy commitments of academic staff to clinical and other duties, usually for financial reasons.

These factors are not conducive to the type of research required to reduce occupation- 
al hazards. Such research should have a strong epidemiological component and some element of rational planning. It demands the collaboration of multidisciplinary teams put together to meet the needs of specific problems. Productive research in this field is seldom short term and ideally follows a rational sequence. Descriptive studies are first required to assess the extent and importance of health problems in terms of frequency and distribution. Given this basic information, complementary research in the field and in the laboratory can then seek to identify causal factors and mechanisms. Later, the research program will become increasingly concerned with evaluating the effectiveness and cost-benefit of control measures.

I hope that research at UOEH comes to acquire an orderly character of this kind with establishment of multidisciplinary teams in each of the main areas of occupational health concern. The approach need not entail any weakening of the departmental structure which remains essential for teaching purposes and the maintenance of scientific standards in the main disciplines. It does require, however, that long-term public or private support be found to finance major research programs such as are proposed. It will also necessitate access to and collaboration with industry on a greatly augmented scale. Information is conflicting on how easy these steps will be.

\section{Service}

It is essential that the University establish a role for itself within the national occupational health services; it is desirable that it should also do so internationally. Ideally situated in one of Japan's largest industrial conurbations, it is clear to me that the University should concentrate on the design and implementation of services for the industries of Kitakyushu. This might include the development of an information and advisory service and probably some type of co-operative scheme for small industries. The latter is a difficult task which may call for trial and evaluation of various models. The experience and, hopefully, success of these various activities in Kyushu could have much wider application. It would certainly provide a field for student training, ideas and facilities for research, and offer staff the opportunity for important and rewarding practical work.

Japan's unrivalled status in the Eastern hemisphere bring responsibilities and risks. By virtue of industrial sophistication and wealth it is in a position to help less developed nations of the region in many ways. At the same time, any suggestion of neo-colonial paternalism or self-serving generosity are clearly to be avoided. There are ways in which a wealthy country can be truly helpful, so long as it provides the aid requested rather than what it wants to offer. Help in the establishment of educational and research facilities in less favored countries is something to which UOEH might aspire in time. An urgent international problem where leadership from Japan would be particularly appropriate relates to the safe use in the Third World of used (and new) factory machinery imported from the more industrialized countries. The exportation of chemical products has created analogous hazards for which codes of practice and information sys- 
tems are needed. The effective adoption by UOEH of a problem of this nature and scope could do much for the University's international reputation.

\section{Synthesis}

During my next appointment as a visiting professor at this University, in $10-15$ years time, I hope to find that it has lived up fully to its name. Its school of medicine will be one among several undergraduate schools, and there will be a thriving postgraduate school of occupational and environmental health sciences. It will have established itself as the leading center in this part of the world for training a range of specialists in occupational health and will have helped create the best system of further education in the world for occupational health workers in practice. It will have a well-balanced set of multidisciplinary teams systematically engaged in longterm research programs dedicated to the control of Japan's priority problems of health and safety at work. It will have set up and tested the first comprehensive system of occupational health for large and small industries in a major industrial area. It will have demonstrated by research the ways in which a responsible industrial society can ensure the safe use of its exported machinery and materials to the developing world. That might be a good occasion for my next lecture.

\section{References}

Division of Statistics, Ministry of Labour (1980): Occupational Health and Safety in Manufacturing Industries: Basic Analyses. Tokyo.

Japan Industrial Safety and Health Association (1983): Industrial Safety and Health Law and Related Legislation of Japan. JISHA, Tokyo. (in English)

McDonald, J. C. (1981): Four pillars of occupational health. Brit. Med. J., 282: 83-84, 88.

Statistics and Information Department, Minister's Secretariat, Ministry of Labour, Japan (1983): Year Book of Labour Statistics, 1981. Tokyo.

Tsuchiya, K. (1982): Characteristic features of occupational health service in Japan. J. UOEH, 4: $51-63$.

Tsuchiya, T. (1983): The Aims of the University of Occupational and Environmental Health, Japan. Bull. UOEH, 1983-1984, pp. i-iii. 
日本における産業医学

一産業医科大学に望むもの一

\section{コーベット マクドナルド (Corbett McDonald)}

マクギル大学産業保健学部 (School of Occupational Health) 教授 産業医科大学訪問教授 (Oct.-Nov., 1983)

要旨：産業医科大学に $10-15$ 年後に再び，訪問教授(Visiting Professor) として岸ってきた時 に私は，当大学がその名前にふさわしい大学として完全にできあがっていることを望むも のである，医学部は，他の学部のうちの一学部になっているであるうし，特に，産業・環 境保健科学の卒後教育施設 (postgraduate school) が充実しているのを見るのが楽しみで ある。そその時には，当大学は㦃業保健における一連の尃門家養成のための，アジア地域に おける先導的なセンターとして完成しているであろうし，産業保健実務者のための生涯教 育について最善のシステムを創り，それは世界の模範となっているであうう。更に，当大 学では日本における職場の安全衛生の重要な問題解決に貢献すべく, 長期の研究計画に従 事する学際的且つ調和のある系統的なチームができあがっていることであろう。また，重 要な産業領域に㧍ける大・小企業のための産業保健の, 最初の総合的なシステムを組織し, 且つ具現化していることであろう，当大学の研究を基本として，産業社会が発展途上国に 輸出する機械や物質を, 安全に使用できるよう責任をもって確約するための方策を提示し ているであるう。これらのことが達成されている 10-15年後こそ, 私の次の講演にとっ て良い機会であると信ずる。

J. UOEH（産業医大誌）， 6(2): 209-219 (1984) 